\title{
Permeability of Gas Vesicles to Perfluorocyclobutane
}

\author{
By A. E. WALSBY \\ Department of Botany, University of Bristol, Bristol BS8 1UG, U.K.
}

(Received 6 November 1981)

\begin{abstract}
The permeability of intact gas vesicles, isolated from the cyanobacterium Anabaena flos-aquae, to percyclofluorobutane $\left(\mathrm{C}_{4} \mathrm{~F}_{8}\right)$, has been investigated by two methods. Warburg manometry showed that a suspension of intact gas vesicles exchanges more $\mathrm{C}_{4} \mathrm{~F}_{8}$ than an equivalent suspension of collapsed ones. Pressure nephelometry showed that increasing the partial pressure of $\mathrm{C}_{4} \mathrm{~F}_{8}$ in solution caused a corresponding increase in apparent critical collapse pressure of the gas vesicles. From these observations it is concluded that $\mathrm{C}_{4} \mathrm{~F}_{8}$ is able to permeate freely through the gas vesicle wall. If it permeates via pores, these must be at least as large as the gas molecules, which have a collision diameter of $0.63 \mathrm{~nm}$. Warburg manometry showed that the volume of $\mathrm{C}_{4} \mathrm{~F}_{8}$ exchanged exceeds the volume of gas-vesicle gas space, and this indicates that, in addition, there is specific absorption of the gas, probably on the inner, gas-facing surface of the gas vesicle wall.
\end{abstract}

\section{INTRODUCTION}

The gas vesicle of prokaryotic micro-organisms is a hollow, rigid structure, formed from a shell of protein (see Walsby, 1972). The space inside the structure, which is free of solid or liquid substances, normally contains gas because the proteinaceous wall is permeable to the atmospheric gases. When the gas vesicle is suspended in water the dissolved gases equilibrate freely across the gas vesicle wall and their partial pressures inside the structure will be identical to those of the gases in the surrounding solution. Inside the living micro-organisms, therefore, the gas vesicle will usually contain air in which the proportions of the constituent gases are modified by the metabolic activities of the surrounding cytoplasm (Walsby, 1969).

Previous studies have shown that gas vesicles are freely permeable to nitrogen, oxygen, argon, carbon dioxide, carbon monoxide, hydrogen and methane (Walsby, 1969, 1971). The gas vesicle is a rigid structure (Walsby, 1971). It is made up of a single type of protein arranged in a crystalline array and the adjacent protein molecules are locked together in a $\beta$-sheet configuration by hydrogen bonding (Blaurock \& Walsby, 1976). In such a structure it is likely that the gases which permeate it must pass by channels or pores that occur either within or, more probably, between the individual protein molecules. If so, the pores must be large enough to accommodate the permeating gases.

An estimate of the pore size of porous structures can be obtained from the sizes of molecules which either permeate or are excluded from them. In studies with porous zeolite crystals with apertures of known size, it was demonstrated that the best estimate of pore size would be obtained from the collision diameter $(\sigma)$ of the largest molecules which permeate (Breck, 1974). The largest of the molecules so far shown to permeate the gas vesicle is methane, $\sigma=$ $0.38 \mathrm{~nm}$.

In this paper I report the permeability of gas vesicles to perfluorocyclobutane $\left(\mathrm{C}_{4} \mathrm{~F}_{8}\right)$, a gas with a molecular collision diameter $\sigma=0.63 \mathrm{~nm}$. Two methods have previously been used to demonstrate that gas vesicles are permeable to particular gases. The first used Warburg manometry to demonstrate that the amount of extra gas exchanged by a suspension 
containing intact gas vesicles depended on the volume enclosed by the intact gas vesicles present (Walsby, 1969). This method could be used without modification with $\mathrm{C}_{4} \mathrm{~F}_{8}$ but produced anomalous results, suggesting specific absorption by the vesicles. The second method used to demonstrate gas permeability was to take a suspension of gas vesicles spread in a thin film and to show that the vesicles survived gas pressures well in excess of their critical collapse pressure if the gas pressure was raised slowly enough (Walsby, 1971). They survive because as the overlying gas pressure is raised the gas diffuses into the suspending solution and through the gas vesicle wall so that the differential pressure across the wall required to cause collapse (known as the critical pressure) is not achieved. This experiment per se cannot be carried out with $\mathrm{C}_{4} \mathrm{~F}_{8}$ because its saturation vapour pressure is about only 2.3 bar $(0.23 \mathrm{MPa})(1.25$ bar above ambient pressure) whereas the mean critical pressure of the gas vesicles used is about 6 bar. However, a modification of this experiment was devised to demonstrate that $\mathrm{C}_{4} \mathrm{~F}_{8}$ did penetrate the gas vesicle and contribute to the gas pressure inside it.

\section{METHODS}

Isolation of gas vesicles. Intact gas vesicles were isolated from the strain of Anabaena flos-aquae used in previous investigations (see Booker \& Walsby, 1979) and maintained in the Culture Centre of Algae and Protozoa, Cambridge, U.K., as culture 1403/13f. The procedure used for gas vesicle isolation was that described by Walsby \& Buckland (1969) as modified by Armstrong \& Walsby (1979).

Warburg manometry. The gas exchange capacity of the gas vesicle suspensions was measured using the modified Warburg apparatus identical to that described by Walsby (1969) in all respects except that the sensitivity of the apparatus was increased approximately threefold by reducing the size of the flasks and the free gas space in the manometer.

The same weight of an intact gas vesicle suspension, $2.14 \mathrm{~g}$, was placed in each of two Warburg flasks. The gas vesicles in one of the flasks were collapsed by pressurizing rapidly to 16 bar, in the pressure cylinder described by Walsby (1971). The sample was pressurized several times, with intervening mixing to collapse gas vesicles which survived near the surface of the suspension on the first pressurization. The volume of suspension in the first flask $(2.21 \mathrm{ml})$ was calculated after measuring the density of gas vesicle suspension $\left(0.970 \mathrm{~g} \mathrm{~cm}^{-3}\right)$ in a specially constructed stoppered glass tube with $0.2 \mathrm{~mm}$ bore capillary tube attached. Using the same device the volume of gas-filled space in the suspension ( $25 \mu \mathrm{l}$ gas space per $\mathrm{ml}$ of suspension) was determined, and from this figure the volume of the pressurized suspension $(2.16 \mathrm{ml})$ was calculated.

The flasks were attached to their manometers and equilibrated with shaking, at 120 times $\min ^{-1}$. under air. The pressure of the overlying gas phase was reduced to approximately $0.3 \mathrm{~atm}$ and the amount of gas subsequently evolved from the suspension in each flask was determined from measurements made on the manometer, using the method described in detail by Walsby (1969). Air was readmitted, returning the gas phase to ambient pressure, and the amount of gas taken up by the suspensions was again measured. This cycle of measurements was repeated to provide an estimate of the gas vesicle gas space that was available to gas exchange, in the first flask.

The gas phase was next flushed with $\mathrm{C}_{4} \mathrm{~F}_{8}$ by repeatedly evacuating and filling with the gas, while shaking to equilibrate with the gas dissolved in the suspensions. The amount of $\mathrm{C}_{4} \mathrm{~F}_{8}$ taken up by the suspension on increasing the gas pressure, and evolved by the suspension on decreasing the gas pressure, was then measured on two successive cycles, as previously described for air. The flasks were then re-equilibrated with air and the gas exchange capacity remeasured with air, to check that the volume of intact gas vesicles was not changing during successive cycles. (There was no significant change, see Table 1). Finally, the flasks were again re-equilibrated with $\mathrm{C}_{4} \mathrm{~F}_{8}$ and its gas exchange was re-measured.

The following other details were used in calculating the data given in Table 1. (a) The volumes of the gas phases $\left(V_{\mathrm{g}}^{\prime}, V_{\mathrm{g}}\right)$ over the suspensions with intact and collapsed gas vesicles were $8.344 \mathrm{ml}$ and $8.160 \mathrm{ml}$, respectively, in runs 1 to 9 and $8.526 \mathrm{ml}$ and $7.985 \mathrm{ml}$, respectively, in runs 10 to 16 . The flasks and manometers were exchanged after run 10 to eliminate the possibility of a specific flask effect. (b) The amount of gas evolved from the intact gas vesicles after a given pressure change was calculated from the expression given by Walsby (1969; equation 8):

$$
\left[\left(h^{\prime} V_{\mathrm{g}}^{\prime}-h V_{\mathrm{g}}\right)(273 / T)+V_{\mathrm{f}} c\left(h^{\prime}-h\right)\right] / P_{0}
$$

where $h^{\prime}$ is the rise in the level of the Warburg manometer fluid after equilibration in the flask with intact gas vesicles, $h$ is the rise in the flask with collapsed gas vesicles, $T$ is the absolute temperature, $V_{f}$ is the volume of water in the gas vesicle suspensions $(2.149 \mathrm{ml}$, the volume of the suspension of collapsed gas vesicles less the volume of collapsed vesicles), $\alpha$ is the absorption coefficient of the gas $\left(0.0186\right.$ for air and 0.0056 for $\left.\mathrm{C}_{4} \mathrm{~F}_{8}\right)$, and $P_{0}(=$ 
10000) is the standard pressure in mm of the manometer fluid, Brodie's fluid. (c) The volume of the gas-vesicle gas space in the suspension was calculated from the volume of air exchanged using the expression

$$
V_{\mathrm{gv}}=\left[\left(h^{\prime} V_{\mathrm{g}}^{\prime}-h V_{\mathrm{g}}\right)+V_{\mathrm{f}} \alpha(T / 273)\left(h^{\prime}-h\right)\right] /\left(P-P^{\prime}-h^{\prime}\right)
$$

given by Walsby (1969; equation 9), where $P-P^{\prime}$ is the initial change in pressure of the gas phase. (d) The volumes of gas evolved into the gas phase after a pressure change, plotted in Fig. 1, were calculated using the expression $x=h V_{g}(273) / T P_{0}$.

Measurement of gas vesicle collapse pressures. The proportion of gas vesicles collapsing under pressure was determined from measurements of light scattering made with a pressure nephelometer as described by Walsby (1973, 1980). Measurements were made after equilibrating the gas vesicle suspension with air at the ambient pressure, and also after shaking with air or $\mathrm{C}_{4} \mathrm{~F}_{8}$, at a pressure of 1.25 bar above the ambient pressure, for several minutes, in the nephelometer tube. In the experiments performed with $\mathrm{C}_{4} \mathrm{~F}_{8}$ the gas vesicle suspension was first bubbled with the gas to remove dissolved air and the gas space above the nephelometer tube was filled and emptied five times with the gas, also to displace air.

\section{RESULTS AND DISCUSSION}

\section{Warburg manometry}

When the air pressure was decreased over the suspensions of isolated gas vesicles that had been equilibrated with air at ambient pressure, gas was gradually evolved into the overlying gas phase and measured on the Warburg manometer. As shown in Fig. 1, more gas was evolved from the suspension of intact vesicles than from the suspension of collapsed gas vesicles. From the difference in volume of gas evolved from the two suspensions, the volume of gas-vesicle gas space in the suspension of intact vesicles can be calculated using the equations of Walsby (1969). The results of a series of gas-exchange measurements made following increases or decreases in the overlying air pressure are summarized in Table 1.

After the Warburg manometry experiments with air and with $\mathrm{C}_{\mathbf{4}} \mathrm{F}_{\mathbf{8}}$ (reported below), samples of the suspension of intact vesicles were taken and the volume of gas vesicle gas space was determined by compression in the special capillary tube. From these measurements the original volume of gas vesicle gas space in the Warburg fiask was calculated to be $56.2 \pm$ $5.7 \mu \mathrm{l}$ (95\% confidence limits). This is in agreement with the value obtained by Warburg manometry, $55 \cdot 1 \pm 9.2 \mu \mathrm{l}$, and confirms that no significant irreversible change occurred in the volume of gas vesicles after exposure to $\mathrm{C}_{4} \mathrm{~F}_{8}$.

The measurements of gas exchange using $\mathrm{C}_{4} \mathrm{~F}_{8}$ showed a number of differences (see Fig. 1 and Table 1). First, the rate of gas exchange was slower than for air; this is to be expected because the exchange rate depends on the rate of diffusion which, by Graham's law, is slower for a larger gas molecule. Secondly, the volume of $\mathrm{C}_{4} \mathrm{~F}_{8}$ taken up by the suspension of collapsed gas vesicles was about a third of the volume of air taken up, following a similar rise in gas pressure; this is also expected because the solubility coefficient of $\mathrm{C}_{4} \mathrm{~F}_{8}$ in water $\left(0.0056\right.$ at $25^{\circ} \mathrm{C}$; P. Rathbone, personal communication) is about a third of that of air $(0.0186)$. Thirdly, the volume of $\mathrm{C}_{4} \mathrm{~F}_{8}$ taken up by the suspension of intact gas vesicles was substantially greater than the volume of air that was taken up. Because the rate of uptake was so slow and decreased with time, it was uncertain whether the system had come fully to equilibrium even after shaking for an hour or more. The release of gas from solution, following partial evacuation of the overlying gas phase, similarly proceeded very slowly.

There was nothing anomalous about the absorption of $\mathrm{C}_{4} \mathrm{~F}_{8}$ by the suspension of collapsed gas vesicles, but the extra amount absorbed by the intact vesicles exceeded the volume of gas space they enclosed. This seemed to indicate that there must be some specific absorption or condensation of the $\mathrm{C}_{4} \mathrm{~F}_{8}$ on or in the intact vesicles. In a sense, if there had to be some specific absorption to explain the anomalous results, it remained to be proved that any of the uptake resulted from the gas entering the gas spaces of the gas vesicles. However, this was demonstrated by another type of experiment. 


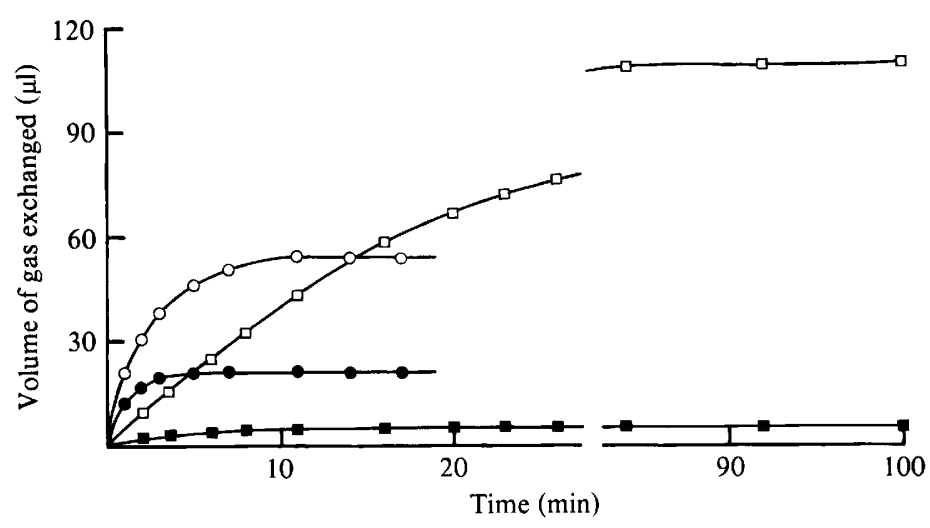

Fig. 1. Gas taken up by a suspension of intact gas vesicles (open symbols) and an equivalent suspension of collapsed gas vesicles (filled symbols) following a pressure rise in the overlying gas phase containing: air, pressure rise 0.68 bar $(O, O)$, or $C_{4} F_{8}$, pressure rise 0.67 bar $(\square$, $\square$ ).

Table 1. Gas exchange by equivalent suspensions of intact and collapsed gas vesicles following changes in pressure of the overlying gas phase

\begin{tabular}{|c|c|c|c|c|c|c|c|}
\hline \multirow[b]{3}{*}{ Gas } & \multicolumn{7}{|c|}{ Pressure change (mm Brodie's fluid) } \\
\hline & & \multirow{2}{*}{$\begin{array}{l}\text { Equilibration } \\
\text { time } \\
(\mathrm{min})\end{array}$} & \multirow{2}{*}{$\begin{array}{c}\text { Initial } \\
\text { change } \\
\left(P-P^{\prime}\right)\end{array}$} & \multicolumn{2}{|c|}{$\begin{array}{l}\text { Resulting change over } \\
\text { suspension of }\end{array}$} & \multirow{2}{*}{$\begin{array}{l}\text { Vol. of } \\
\text { gas evolved } \\
\text { from gas } \\
\text { vesicles } \\
(\mu \mathrm{I})\end{array}$} & \multirow{2}{*}{$\begin{array}{l}\text { Calculated } \\
\text { vol. of } \\
\text { gas } \\
\text { vesicles } † \\
\text { (jil) }\end{array}$} \\
\hline & Run & & & $\begin{array}{c}\text { Intact } \\
\text { vesicles }\end{array}$ & $\begin{array}{c}\text { Collapsed } \\
\text { vesicles }\end{array}$ & & \\
\hline Air & $\begin{array}{r}1 \\
2 \\
3 \\
4 \\
9 \\
10 \\
11 \\
12\end{array}$ & $\begin{array}{l}13 \\
15 \\
11 \\
13 \\
11 \\
11 \\
14 \\
16\end{array}$ & $\begin{array}{r}-7079 \\
7079 \\
-7750 \\
6500 \\
6738 \\
-6553 \\
6553 \\
-6447\end{array}$ & $\begin{array}{r}78 \\
-72 \\
82 \\
-60 \\
-75 \\
72 \\
-79 \\
71\end{array}$ & $\begin{array}{r}31 \\
-21 \\
39 \\
-21 \\
-30 \\
36 \\
-39 \\
28\end{array}$ & $\begin{array}{l}39.6 \\
42.8 \\
36.8 \\
33.1 \\
37.9 \\
32.9 \\
36.4 \\
38.4\end{array}$ & $\begin{array}{l}56 \cdot 5 \\
61.0 \\
48 \cdot 0 \\
51.4 \\
56 \cdot 8 \\
50 \cdot 6 \\
56 \cdot 2 \\
60 \cdot 2\end{array}$ \\
\hline $\mathrm{C}_{4} \mathrm{~F}_{8}$ & $\begin{array}{r}5 \\
6 \\
7 \\
8 \\
13 \\
14 \\
15 \\
16\end{array}$ & $\begin{array}{r}100 \\
83 \\
43 \\
87 \\
55 \\
52 \\
44 \\
39\end{array}$ & $\begin{array}{r}6713 \\
-6118 \\
6040 \\
-6566 \\
6355 \\
-6671 \\
6276 \\
-6315\end{array}$ & $\begin{array}{r}-140 \\
99 \\
-115 \\
119 \\
-128 \\
100 \\
-86 \\
77\end{array}$ & $\begin{array}{r}7 \\
0 \\
7 \\
-9 \\
0 \\
3 \\
-7 \\
-7\end{array}$ & $\begin{array}{r}111.3 \\
82.7 \\
90.4 \\
92 \cdot 1 \\
109.3 \\
83 \cdot 0 \\
68 \cdot 2 \\
71 \cdot 2\end{array}$ & $\begin{array}{l}169.6 \\
137.5 \\
152 \cdot 5 \\
142.8 \\
175 \cdot 5 \\
126 \cdot 3 \\
110 \cdot 2 \\
114.4\end{array}$ \\
\hline
\end{tabular}

- Equilibrium was not achieved in all of the $\mathrm{C}_{4} \mathrm{~F}_{8}$ runs.

$\dagger$ On the assumption that there is no specific absorption, which is obviously invalid for $C_{4} F_{8}$.

\section{Effect of dissolved $C_{4} F_{8}$ on the pressure required to collapse gas vesicles}

An aqueous suspension of gas vesicles was saturated with air at the ambient pressure by shaking for several minutes. Because the gas vesicles are known to be freely permeable to air it is known that they will have filled with air at the ambient pressure. The collapse of the gas vesicles with pressure was investigated by pressure nephelometry and it was found that $50 \%$ collapsed at a pressure of 5.9 bar above the ambient pressure (Fig. 2). Thus 5.9 bar is the mean critical pressure of the vesicles.

When samples of the same gas vesicle suspension were shaken with air at a pressure of 1.3 bar above the ambient pressure for $2 \mathrm{~min}$, the pressure required to collapse $50 \%$ of the 


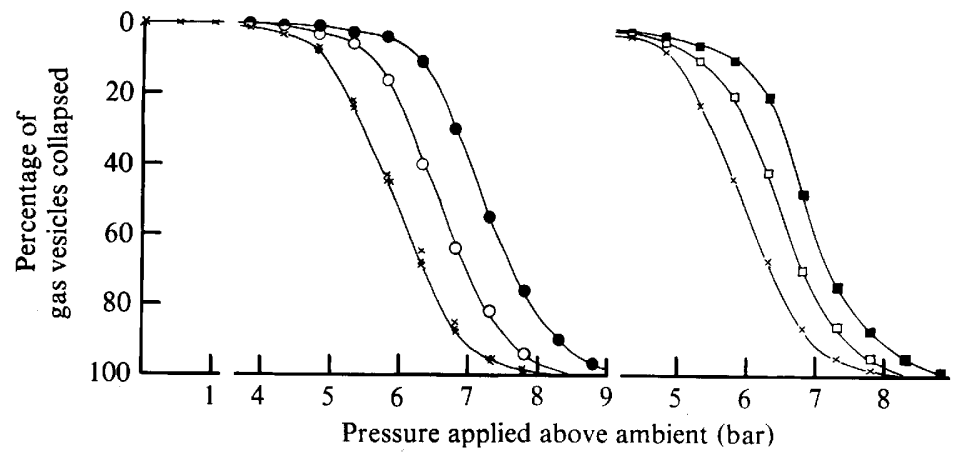

Fig. 2. Collapse of isolated gas vesicles with pressure: after equilibrating the suspension with air at ambient pressure $(x)$; after shaking with air at a pressure of 1.3 bar for $2 \min (O)$ and for $5.5 \mathrm{~min}(O)$; after shaking with $\mathrm{C}_{4} \mathrm{~F}_{8}$ at a pressure of 1.3 bar for $2 \mathrm{~min}(\square)$ and for $8 \mathrm{~min}(\square)$, average of two readings. The pressures shown on the $y$ axis are pressures above the ambient pressure.

gas vesicles increased to 6.6 bar, and after 5.5 min shaking it increased by 1.3 bar to 7.2 bar (Fig. 2). No further increase occurred on shaking for longer periods. The increase in $50 \%$ collapse pressure by 1.3 bar indicated that the air had equilibrated throughout the system, from the overlying gas phase through the suspension to the gas spaces of the vesicles.

Similar measurements were carried out after shaking the gas vesicle suspension with $\mathrm{C}_{4} \mathrm{~F}_{8}$ for different times. After 2 min shaking the $50 \%$ collapse pressure had risen to 6.4 bar, after $5 \mathrm{~min}$ it had risen to $6.8 \mathrm{bar}$, and after $8 \mathrm{~min}$ shaking it had risen by 1.0 bar to 6.9 bar (Fig. 2). Evidently the $\mathrm{C}_{4} \mathrm{~F}_{8}$ took much longer to equilibrate than the air, as also indicated by the Warburg experiments. However, it is clear that it had entered the gas vesicles as a gas and was generating a pressure which helped prevent collapse of the structures. It should be mentioned that if the $\mathrm{C}_{4} \mathrm{~F}_{8}$ had not entered the gas vesicles, their $50 \%$ collapse pressure would have decreased by 1 bar because purging the air from the suspension would anyway have removed air from the gas vesicles, and it has already been demonstrated that the apparent critical pressure decreases by 1 bar after a suspension has been degassed by evacuation (Walsby, 1971).

Since in these experiments, with gentle shaking in the nephelometer tube, $70 \%$ equilibrium was attained between the $\mathrm{C}_{4} \mathrm{~F}_{8}$ in the gas-vesicle and overlying gas space in only $8 \mathrm{~min}$, full equilibrium must have been attained in the Warburg experiments after more prolonged and vigorous shaking. It is, therefore, possible to estimate the proportions of the total gas taken up that (1) entered the gas spaces and (2) was specifically absorbed by the walls of the gas vesicles. Thus, in Warburg experiment 5 , for example, where $170 \mu \mathrm{C}_{4} \mathrm{~F}_{8}$ was absorbed after a pressure change of $0.66 \mathrm{~atm}, 56 \mu \mathrm{l}$ of this would be present as free gas inside the gas vesicles. The difference, $114 \mu \mathrm{l}$ at $0.66 \mathrm{~atm}$ pressure (equivalent to $3.34 \mu \mathrm{mol}$ or $668 \mu \mathrm{g}$ $\mathrm{C}_{4} \mathrm{~F}_{8}$ ), must be the amount specifically absorbed by the gas vesicles. According to data of Armstrong \& Walsby (1979), $1 \mathrm{mg}$ of gas vesicle wall encloses $7.67 \mu \mathrm{l}$ of gas space; the $56 \mu \mathrm{l}$ of gas space therefore represents $7.3 \mathrm{mg}$ of wall protein and the specific absorption is equivalent to $92 \mu \mathrm{g}$ of gas per $\mathrm{mg}$ protein, when the partial pressure of $\mathrm{C}_{4} \mathrm{~F}_{8}$ is increased from 0.34 to $1.0 \mathrm{~atm}$.

The peculiar feature of the additional absorption of $\mathrm{C}_{4} \mathrm{~F}_{8}$ is that it occurs with intact but not collapsed gas vesicles. One possible explanation for this is that the $\mathrm{C}_{4} \mathrm{~F}_{8}$ condenses in pores present between protein molecules in the intact vesicles, but that these pores close up when the rounded form of the structure is collapsed to a flattened envelope. Another, perhaps more likely, explanation is that the $\mathrm{C}_{4} \mathrm{~F}_{8}$ condenses on the hydrophobic inner surface of the intact gas vesicle (Worcester, 1975; Walsby, 1978), but when the vesicle is collapsed the two halves of the broken structure are pressed together and this inner surface is no longer available for absorption. We have started investigations into the nature of the absorption by 
studying absorption isotherms of $\mathrm{C}_{4} \mathrm{~F}_{8}$ using freeze-dried gas vesicles, and have confirmed that specific absorption does occur (J. Green, J. M. Haynes \& A. E. Walsby, unpublished results).

It has been shown here that $\mathrm{C}_{4} \mathrm{~F}_{8}$ is able to penetrate the wall of the gas vesicle. When Danielli and Davson (1935) considered the permeability of membranes to small molecules they concluded that 'penetration must in all cases, whether it occurs through a solid or liquid film, take place through an interspace; this is a precondition for penetration accepted at least tacitly, by the advocates of both the pore theory and the solubility theory of permeability.' They considered that such interspaces had a fleeting existence in liquid films where the constituent molecules have great mobility, but in more solid structures it was possible to have pore structures of molecular dimensions with a relatively permanent existence. As mentioned above, the wall of the gas vesicle is a rigid structure in which there can be little mobility of the constituent protein molecules, beyond the vibrational movements associated even with solid structures. It is likely, therefore, that the interspaces penetrated by the $\mathrm{C}_{4} \mathrm{~F}_{8}$ gas molecules constitute pores of fixed position within the gas vesicle wall. These pores must have a minimum diameter of $0.63 \mathrm{~nm}$, the collision diameter of $\mathrm{C}_{4} \mathrm{~F}_{8}$, and for reasons discussed previously (Walsby, 1972), it is more likely that they occur between rather than within the constituent protein molecules of the gas vesicle wall.

I am most grateful to Drs P. J. Thomas and P. Rathbone of Imperial Chemical Industries Limited, Mond Division, for providing a sample of percyclofluorobutane and information on its physical properties, and to Professor D. H. Everett F.R.S. for discussions on gas permeability. This work was supported by a grant from the Science and Engineering Research Council.

\section{REFERENCES}

Armstrong, R. E. \& Walsby, A. E. (1979). Average thickness of the gas vesicle wall. Journal of Molecular Biology 129, 279-285.

Booker, M. J. \& WALsBY, A. E. (1979). The relative form resistance of straight and helical blue-green algal filaments. British Phycological Journal 14, 141-150.

BRECK, D. W. (1974). Zeolite Molecular Sieves. New York: Wiley.

Blaurock, A. E. \& Walsby, A. E. (1976). Crystalline structure of the gas vesicle wall from Anabaena flos-aquae. Journal of Molecular Biology 105, 183-199.

Danielli, J. F. \& Davson, H. (1935). A contribution to the theory of permeability of thin films. Journal of Cellular Physiology 5, 495-508.

WALSBY, A. E. (1969). The permeability of blue-green algal gas-vacuole membranes to gas. Proceedings of the Royal Society of London B173, 235-255.

WALSBY, A. E. (1971). The pressure relationships of gas vacuoles. Proceedings of the Royal Society of London B 178, 301-326.
WALSBY, A. E. (1972). Structure and function of gas vacuoles Bacteriological Reviews 36, 1-32.

W ALSBY, A. E. (1973). A portable apparatus for measuring relative gas vacuolation, the strength of gas vacuoles, and turgor pressure in planktonic blue-green algae and bacteria. Limnology and Oceanography 18, 653-658.

W ALSBY, A. E. (1978) The gas vesicles of aquatic prokaryotes. Symposia of the Society for General Microbiology 28, 327-358.

W ALSBY, A. E. (1980). The water relations of gas-vacuolate prokaryotes. Proceedings of the Royal Society of London B208, 73-102.

Walsby, A. E. \& BuCKLAND, B. (1969). Isolation and purification of intact gas vesicles from a blue-green alga. Nature, London 224, 716-717.

WORCESTER, D. L. (1975). Neutron diffraction studies of biological membranes and membrane components. Brookhaven Symposia in Biology 27, III, 37-57. 